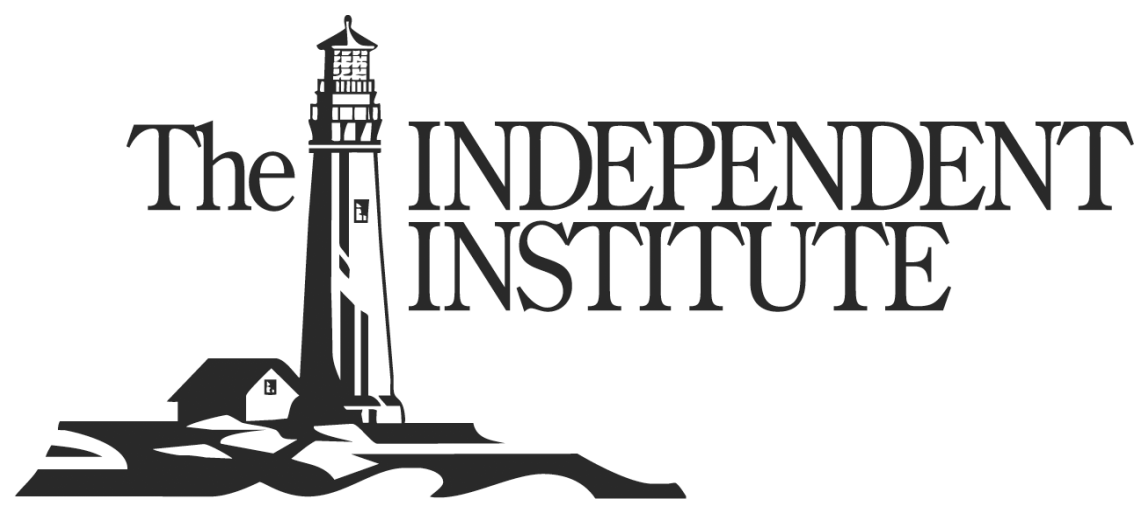

\title{
The Positive Correlation of Price and Concentration in Staples: Market Power or Indivisibility?
}

\section{Craig M. Newmark}

Independent I nstitute Working Paper Number 31

April 2001 


\section{The Positive Correlation of Price and Concentration in Staples: Market Power or Indivisibility?}

Craig M. Newmark

Assoc. Prof. of Economics

April, 2001

North Carolina State University

Dept. of Economics

Box 8110

Raleigh, NC 27695-8110

(919) 513-2878 voice

(919) 515-7873 fax

craig_newmark@ncsu.edu 


\section{Abstract}

The FTC's successful challenge of the Staples-Office Depot merger is one of the most important antitrust cases in recent years. Vital to the FTC's success was evidence that prices for office supplies were significantly higher in markets having only one firm operating office supply superstores than in markets having two or three such firms. The FTC used this evidence to argue that the merger would raise the price of office supplies. This paper applies an idea of Harold Demsetz (1989)_indivisibility rent — to argue that one-firm markets probably have higher marginal costs. If so, the FTC's inference about the effect of the merger is doubtful. 


\section{The Positive Correlation of Price and Concentration in Staples: Market Power or Indivisibility?}

The argument about anticompetitive effect in Staples turned on a single overwhelming fact: prices of office supplies could be shown on average to be substantially higher in cities where only one office supply super store chain was located than where two super store chains competed, and even higher than in cities where the three super store chains all faced each other in the market place.

Robert Pitofsky (1997)

The Commission's success with the price-comparison data suggests that it will likely rely on such evidence in future mergers. Likewise, the Court's embrace of the data confirms its probative value.

Robert W. Doyle, Jr. and D. Reed Freeman, Jr. (1997)

\section{Introduction}

In early 1997 the FTC challenged the proposed merger of two office supply firms, Staples and Office Depot. On June 30, 1997, U.S. District Court Judge Thomas F. Hogan granted the FTC a preliminary injunction; shortly afterward Staples and Office Depot abandoned the merger.

In Staples the FTC applied new economic theory and introduced a new type of evidence. ${ }^{1}$ The case has been described as the "biggest litigated antitrust case in a decade" 2 and "the most controversial and well-contested merger case in decades." ${ }^{3}$ An antitrust expert at Cravath, Swaine \& Moore declared "Had the FTC lost, it would have been in terrible trouble, because in the future many more merging parties would have felt it worth their while to take the FTC on. Instead, merging parties are more likely to be willing to negotiate consent decrees."

Crucial to the FTC's case was data showing that in markets where Staples was the only office supply superstore (OSS) firm, prices were higher than in markets where it competed against Office Depot and Office Max. Prices in Staples-only markets were 13\%

\footnotetext{
${ }^{1}$ Dalkir and Warren-Boulton, 1998, p. 143.

${ }^{2}$ Singer, 1997.

${ }^{3}$ Baer, 1999.

${ }^{4}$ Singer, 1997.
} 
higher than in three-firm markets. ${ }^{5}$ Similarly, prices in Office Depot-only markets were $5 \%$ higher than in three-firm markets. ${ }^{6}$

The FTC employed a compelling example to illustrate its case. It noted that “According to Office Depot's own ads, file folders cost \$1.95 in Orlando, Florida, where it competes with Staples and Office Max, and \$4.17 in Leesburg, Florida, some 50 miles away, where it is the only office supply superstore."7 This example helped persuade the Chairman of the FTC, Robert Pitofsky, to proceed with the FTC's challenge. ${ }^{8}$

And company documents suggested that the pricing pattern was not mere coincidence. Both Staples and Office Depot set prices according to the number of OSS firms present in the market. One Office Depot memo stated, "We have one pricing zone in our company that is made up of stores that do not have any superstore competition. ... This zone contains the highest-priced stores in our company, as these stores do not have any competition." A Staples document defined "competitive" markets as markets with another OSS firm and "noncompetitive" markets as markets without another OSS firm. ${ }^{10}$

The Staples defendants argued that higher prices in one-firm markets could result from a "host of factors other than superstore competition." 11 Their consulting economist, Jerry Hausman, estimated a fixed-effects regression model which tried to hold these other factors constant. It indicated that prices would decline following the merger. But Judge Hogan was unmoved. Participants from both sides agreed that the clear-cut price differences across markets combined with the company documents attributing these price differences to differences in competition overpowered the defense case. ${ }^{12}$

In this paper I attempt to fortify two key weaknesses in the defense case. First, why should we expect economic conditions to be different in one-firm markets? The defense offered evidence that some costs tended to be higher in one-firm markets. But Judge Hogan could dismiss this evidence as fragmentary and insufficient because the defense did not offer a unifying theory for these data, a theory that explained why we should expect costs to be systematically higher in one-firm markets. A second, more important weakness was the defense's inability to reconcile these cost data with their own documents. If prices were higher in one-firm markets simply because costs were higher,

\footnotetext{
${ }^{5}$ Federal Trade Commission v. Staples, Inc. and Office Depot, Inc., p. 15.

${ }^{6}$ Ibid., p. 16.

${ }^{7}$ Federal Trade Commission, “FTC Rejects Proposed Settlement In Staples/Office Depot Merger.” April 4, 1997, p. 1.

${ }^{8}$ Federal Trade Commission, "Plaintiff's Memorandum,” April 10, 1997, p. 9 and Singer, 1997.

${ }^{9}$ Singer, 1997.

${ }^{10}$ Dalkir and Warren Boulton, p. 148, footnote 3. See also Federal Trade Commission, “Plaintiff's Reply,” June 6, 1997, p. 12.

${ }^{11}$ Federal Trade Commission v. Staples, Inc. and Office Depot, Inc., p. 33.

12 George S. Cary, Senior Deputy Director of the FTC, stated (Singer, 1997) "The pricing evidence was first, middle, and last. The pricing evidence was the key evidence." Phillip L. Broyles, Assistant Director of the FTC, said (Broyles and Liebeskind, undated), "I think the story that the documents told — the evidence that we amassed—was so consistent that I think that it would have been hard for anyone to have ultimately found against us." Hausman concluded, "The documents had a strong effect on the outcome of the case." (Hausman and Leonard, undated, p. 2)
} 
why would the defendants imply that markets without other superstore firms were especially attractive?

My explanation applies Harold Demsetz's idea of indivisibility rent. ${ }^{13}$ While testing the explanation appears difficult, I propose it in the hope that it spurs research into an alternative to the FTC's conclusion that "significant price differences between geographic areas are based primarily on the level of office superstore competition."14

\section{The problem of interpreting price-concentration correlations}

For the sake of argument I accept the FTC's definition of the market: consumable office supplies sold in office superstores. ${ }^{15}$ I don't examine whether possible economies of scale from the merger would have created welfare gains sufficient to justify the merger. ${ }^{16}$ And I assume that office supply prices are higher in one-firm markets than in two-firm and three-firm markets despite possible index number difficulties. ${ }^{17}$

I focus instead on how we should interpret a positive correlation between prices and the fewness of sellers, also known as seller concentration. A serious problememphasized decades ago by Demsetz in the context of studies of the correlation of profits and concentration across industries - is that seller concentration should not be assumed exogenous. ${ }^{18}$ Applied to an comparison of prices and concentration within a single industry, the warning has even more force: when the product is supposedly the same across geographic markets, why do the markets have different numbers of firms? Why are some markets more concentrated than others? ${ }^{19}$

Two reasons should be considered. One is that the product/services bundle differs across markets. For example, some consumers, particularly higher-income consumers,

\footnotetext{
${ }^{13}$ Demsetz, 1989.

${ }^{14}$ Federal Trade Commission, "Plaintiff's Reply," June 6, 1997, footnote 6.

${ }^{15}$ Several observers question this market definition. Niskanen, 1997 argued that OSS firms faced competition from other types of stores and ma il order retailers. He observed (p. 3), “. . Wal-Mart alone has about the same revenue from office supplies as would the proposed merger." Donlan, 1997 argued that catalog firms, CompUSA, Home Depot, and Wal-Mart offered competition. Hausman (p. 3) contended that Wal-Mart would constrain any noncompetitive price increases just as it did for toys after a bankruptcy left Toys ' $R$ ' Us as the only toy superstore firm. There is at least some anecdotal evidence in support of this argument. Pascual, 2000 (p. 74) asserts that Costco and Wal-Mart are now competing against the OSSs successfully on "the most profitable product categories, including computer paper and printer cartridges" and that Circuit City and Best Buy are now competing vigorously on computers and related equipment.

${ }^{16}$ Defendants claimed savings of $\$ 4.9$ to $\$ 6.5$ billion over five years and additional, unquantified "dynamic" efficiencies. See Federal Trade Commission v. Staples, Inc. and Office Depot, Inc., pp. 45-48. Smith, 1999 argued that the merger could have produced a net welfare gain even without such cost savings (pp. 51-52).

${ }^{17}$ Discussed in Shughart, 1998, footnote 50.

${ }^{18}$ Demsetz 1973 and 1974.

${ }^{19}$ Edward Lopez, 2001 in this journal briefly raised a similar question (p. 375): “. . . there is no explanation for why Staples and Office Depot compete head-to-head in certain markets but not others." See also William Niskanen, 1997, p. 2 who observed, but did not elaborate, that "the size of the regional market" could affect prices.
} 
tend to demand more retail services and amenities. This demand provides an opportunity for innovative firms. If a few firms outcompete others in serving these customers, the market tends to concentrate. But the added cost of providing additional services and amenities means the "identical" product will be priced higher. A positive correlation between price and concentration could therefore be induced unrelated to market power. ${ }^{20}$

While office supply superstores seem to be very similar across markets, there are some differences that were not explored much in Staples. The fraction of store sales accounted for by general office supplies varied across markets: in one-firm markets, $26.68 \%$; in three-firm markets, $37.29 \%$. The fraction due to computer sales, on the other hand, was highest in Staples-only markets and lowest in three-firm markets. ${ }^{21}$ Also interesting is the variation in advertising expenditures. Both prices and per-store advertising expenses were higher in Staples/Office Max areas than in Staples/Office Depot areas. If advertising provides consumers with at least some benefit, than consumers could conceivably have benefited more from the Staples/Office Max competition than from the Staples/Office Depot competition. ${ }^{22}$

The second reason why seller concentration could vary across markets is the interaction of market size and costs. Even if input prices are identical in all markets and all firms have identical production functions, marginal cost may well be higher in smaller markets. This is so for two reasons. If the market is small enough, even a monopoly firm will be unable to sell enough to operate at the most efficient output level. The market will be served either by shipments from another market (which incur transportation costs) or from a local firm selling a suboptimally small volume. ${ }^{23}$

Even if the market is big enough to support one firm operating at the efficient, minimum-average-cost volume, it may not be big enough to support two. And that brings us to indivisibility rent.

\section{Indivisibility rent}

Let's recall some key features of the model of perfect competition. In the basic version of the model all firms are assumed to be identical. Each firm is a price-taker and has only one decision to make, how much output to produce. Each firm chooses an output level such that marginal cost is equal to market price. If at that output level price is greater than average cost, the firms earn economic profit. Whenever the incumbent firms are earning an economic profit, new firms enter the industry. Entry continues, the model assumes, until the additional output drives market price down to an equilibrium level, the level at which all firms earn zero economic profit.

\footnotetext{
${ }^{20}$ See Newmark, 1990 for further discussion..

${ }^{21}$ Federal Trade Commission v. Staples, Inc. and Office Depot, Inc., p. 36.

${ }^{22}$ Ibid., p. 34.

${ }^{23}$ For further discussion and an application to the Portland cement industry, see Newmark, 1998.
} 
But Demsetz (1989) observed that if there are significant indivisibilities in production the model predicts that entry might not occur, so the equilibrium market price might exceed the zero-profit price. Even perfectly competitive firms might earn economic rent.

Significant production indivisibilities discourage entry because the additional output of an entrant might lower market price below the entrant's average cost. This would cause the entrant to lose money. Suppose, for example, that the price of an item in a particular city is above the competitive price and if an additional 10,000 items per year were put on the market price would drop to the competitive level. But further suppose that for a new firm to earn enough to enter the market, it must expect to sell at least 15,000 items per year at the competitive price. The firm would not enter. The item's price in that city would remain above the competitive level. ${ }^{24}$

For indivisibility to be a plausible cause of higher office supply prices in one-firm OSS markets two things must be true. There must be some factor or factors that create significant indivisibility and there must be a reason why indivisibility would be more severe in one-firm markets.

For office supply superstores there seems to be indivisibility at both the store level and the firm level. At the store level, an important advantage of superstores over traditional office supply stores is that superstores stock, at a minimum, a large number of items, some 5,000 or 6,000. At the firm level, Demsetz argued that an important source of indivisibility is advertising. There is evidence that in OSS markets there are advertising economies of scale. Salkir and Warren-Boulton stated, "Economies of scale in advertising, for example, clearly appeared at the local and regional levels." ${ }^{25}$

Indivisibility might affect one-firm markets more because it is more important if the average-cost-minimizing output for the firm is large relative to market demand. Other things equal, indivisibility will therefore tend to raise prices more in smaller markets. ${ }^{26}$

Are markets with fewer OSS firms smaller? In the court proceedings there are three bits of supportive evidence. An expert witness testified that one-firm markets were "typically" smaller. ${ }^{27}$ Next, consider the FTC's example, emphasized in its press release and court filing, of higher prices in one-firm Leesburg, Florida compared to three-firm Orlando, Florida: note that Leesburg had a population of 14,903 while Orlando's

\footnotetext{
${ }^{24}$ Existing firms could not lower price by selling more because they would be selling along positively-sloped marginal cost curves. Demsetz, 1989, pp. 115-116. See Lambson, 1987, for a mathematical treatment.

${ }^{25}$ Dalkir and Warren-Boulton, 1999, pp. 155-56. A further indication that there are probably substantial multi-store economies of scale in this industry is that the number of OSS firms has decreased nationally, in a only few years, from twenty-three to just three. See Federal Trade Commission v. Staples, Inc. and Office Depot, Inc., pp. 39-40.

${ }^{26}$ Another factor which increases the likely effect of indivisibility is inelasticity of the market demand curve. Demsetz, 1989, p. 115. It should be stressed that indivisibility is not necessarily a simple linear function of market size. See the discussion of testing the indivisibility hypothesis in section $\mathrm{V}$ below.

${ }^{27}$ Federal Trade Commission v. Staples, Inc. and Office Depot, Inc., p. 35.
} 
population was $164.693 .{ }^{28}$ And, last, 15 markets listed by the FTC list as having two firms were, on average, smaller than 27 markets listed that had three firms. The mean population of the two-firm markets was 1,045,309; the mean population of the three-firm markets was 1,769,156. Median population of the two-firm markets was 358,360; median population of the three-firm markets was 1,136,607. (Only five of the fifteen two-firm markets-Baltimore, Louisville, San Diego, Tampa-St. Petersburg, and Washington, D.C.- had a population greater than one-half million while only six of the twenty-seven three-firm markets had a population less than one-half million. $)^{29}$

Indivisibility thus offers a possible explanation of the price differences observed across OSS markets. This explanation does not require us to assume that firms in more concentrated markets behave less competitively. And this explanation is consistent with key elements of Staples. It is consistent most importantly with the company documents that discussed "noncompetitive" markets and that suggested pricing zones were determined by the number of competitors. So-called "non-competitive" markets were more profitable but not from lack of competition per se. They were more profitable because they tended to be markets in which indivisibility rents were being earned.

Similarly, indivisibility rationalizes why higher costs didn't seem to account for the higher prices in one-firm markets. For instance, Judge Hogan heard evidence that advertising cost per-store was higher in Staples-only markets than in two - and three-firm markets. But he contended that these higher costs were not large enough to explain the higher prices in Staples-only markets. ${ }^{30}$ The FTC looked very carefully for cost differences - their economists considered costs beyond those the defense formally presented to Judge Hogan— but didn't find any costs that could explain the higher prices. ${ }^{31}$ But in markets affected by indivisibility, price will exceed average cost, perhaps by a lot. Only if marginal cost were computed would costs "explain" the higher prices, but marginal cost is often difficult to measure with accounting data. ${ }^{32}$

Finally, indivisibility is consistent with the pattern of entry into metropolitan markets. Company documents describe many markets as "saturated," having enough stores that "... there is insufficient demand for new office supply superstores to allow an

\footnotetext{
${ }^{28} 1990$ Census population figures obtained from http://venus.census.gov/cdrom/lookup.

${ }^{29}$ The cities are listed in Federal Trade Commission, "Plaintiff's Memorandum," April 10, 1997, footnotes 23 and 24. Metropolitan area populations were obtained from U.S. Bureau of Economic Analysis, "Regional Economic Information System" at http://fisher.lib.virginia.edu/reis/index.html.

${ }^{30}$ Federal Trade Commission v. Staples, Inc. and Office Depot, Inc., p. 34.

${ }^{31}$ According to the FTC's Jonathan Baker defendants said costs in single-firm markets were higher on average for reasons "other than those we could measure and control for in our equations-perhaps resulting from local zoning provisions or congestion ..." But, Baker continued, "Unfortunately for the parties, this theore tical possibility had negligible support in their documents. Our extensive review turned up no evidence of important unobservable cost variables affecting pricing, except in one city." Baker, 1997, pp. 7-8.

${ }^{32}$ One marginal cost that the FTC might not have been able to account for well is distribution cost. Judge Hogan found that such costs were probably higher for stores located farther from firm distribution centers and the CEO of Staples testified that "typically the smaller markets are further away from the distribution hubs." But the defendants did not present evidence on actual differences in distribution costs. Federal Trade Commission v. Staples, Inc. and Office Depot, Inc., p. 35. See also the discussion in section V below.
} 
entrant to achieve competitive-scale economies."33 The FTC stated, "Even with prices elevated in many markets across the country, entry is not occurring" and "... higher

prices have been profitably maintained without being eroded by new entry." 34 Indivisibility can explain why entry was not occurring in one-firm markets despite their higher prices.

\section{The FTC apparently did not consider indivisibility}

The economic experts for the FTC in Staples analyzed the price differences among markets statistically. The analysis the FTC performed has not been made public; all that has been published is a general description. ${ }^{35}$ (The data it used is not publicly available either.) Based on the description available it does not appear that the FTC considered that indivisibility might help explain the observed prices.

The FTC relied upon a cross-sectional model. They compared the prices at Staples stores located near Office Deport stores to the prices of Staples stores located without nearby Office Depot stores. Their estimated model also included variables for the number and identity of other nearby superstores, the number and identity of potential nonsuperstore competitors, and variables "accounting for exogenous determinants of cost and demand (such as paper prices and 'fixed effect' indicator variables for each sample period)." 36

This description doesn't state whether market size was included in the model. ${ }^{37}$ But note that testing for market indivisibility is more complicated that simply including a linear term in market size. Even if large indivisibilities exist, there is a chance that no rents will be earned. For example, if average cost is minimized at a store size that serves 100,000 people, then markets with 100,000 or 200,000 people will have tend to have lower prices than a market with 150,000 people. Prices in very large markets will be affected little by individual store indivisibilities but could well be affected by multiplestore indivisibilities created by, say, economies of scale in advertising. Indivisibility rents

\footnotetext{
${ }^{33}$ Dalkir and Warren-Boulton, 1999, p. 156.

${ }^{34}$ Federal Trade Commission, "Plaintiff's Memorandum," p. 25 and "Plaintiff's Reply," p. 14.

35 See Baker, 1997. Ashenfelter, et. al., 1998 present some specifics of how the government estimated the firmspecific cost pass-through rate, but that issue is different from the one considered here.

${ }^{36}$ Baker, 1997, footnote 26.

${ }^{37}$ Baker states (1997, footnote 47) that the FTC used market size in a supplementary statistical analysis. The defense had argued that entry of OSS firms into a particular market might be endogenous: high prices might encourage entry. So the FTC estimated a second equation which specified that the number of Staples and Office Depot stores in a market was a function of market size and other variables. They then used this equation to construct an instrumental variable for the number of stores in the price model. But in that use, market size does not address indivisibility either theoretically or empirically. Theoretically, indivisibility implies that entry may not be strongly related to price.

Rather than price inducing entry, both price and entry are functions of indivisibility. Empirically, even if market size is used as an instrumental variable, it will not control for indivisibility unless it also appears as an independent variable in the price equation.
} 
will thus be a nonlinear function of market size, nonlinear in a way difficult to specify $a$ priori. $^{38}$

\section{Testing indivisibility against market power}

The indivisibility theory for the Staples price differences predicts differently than the FTC's market power theory. According to the FTC's theory, OSS firms set prices primarily by how many other OSS firms compete in the metropolitan area. Since the merger would reduce that number in many areas, prices would necessarily rise. The indivisibility theory implies that the higher prices in one-firm markets are not due to lack of competition; the merger should not raise prices. ${ }^{39}$

The obvious question is how can the indivisibility theory be tested empirically against the FTC's market power theory? The direct way would be to demonstrate that marginal costs are negatively correlated with the number of firms and in particular, that one-firm markets tend to have higher marginal costs than two - and three-firm markets.

But that would be difficult. The profits-concentration literature discussed for years the difficulty of extracting economic costs from accounting data. Determining marginal marketing, warehousing, information-systems, and transportation costs for office supply superstores is similarly challenging. Even a cost apparently easy to measure-labor expense-can involve difficulties. For example, Dunne and Roberts, using plant-level data, estimated a reduced-form equation for the price of bread. They found that production workers' wages were not significant while non-production workers' wages were significant but negatively related to price. They decided that the most likely explanation for the second result was that wage rates for non-production workers reflected differences in worker quality. ${ }^{40}$

Defense expert Jerry Hausman tried a different approach. Rather than attempt to control for costs across markets, he estimated a fixed-effects model. He looked at the prices in Staples stores in a market over time; specifically, he looked at how prices in Staples stores changed following the entry into the market of Office Depot stores. He

\footnotetext{
${ }^{38}$ Population should be a good proxy for market size, but more refined measures should also be examined. A lot of OSS sales are to small businesses. The type of small businesses in an area is thus important in determining the size of the market. For example, it seems likely that white-collar businesses buy more office supplies than blue-collar businesses.

${ }^{39}$ The reader may wonder if the merger reduced the number of OSS firms in a market from two to one and the market structure changed from competition to monopoly, wouldn't price have to rise? Doesn't our textbook model of monopoly mandate that conclusion? My answer is "not necessarily." One reason: the change from competition to monopoly does not have to raise market price if the monopolist has lower costs than the competitors did. The Staples defendants claimed exactly that, that the merger, itself, would decrease costs. Another reason is that even monopolists can be disciplined by potential entry. And a final reason is that our text book model of monopoly assumes that there is no uncertainty about the definition of the market. In virtually all reatworld markets, the proper definition of the market is uncertain. In case of OSS firms, a "monopolist" that tried to exploit its market power might well induce competition from other vendors of office supplies. See footnote 15.

${ }^{40}$ Dunne and Roberts, 1992, pp. 23-25.
} 
argued that with this approach, "economic factors other than the presence of Office Depot were held constant." 41

Hausman estimated that the merger would raise prices only $1.3 \%$, if at all. ${ }^{42}$ This was much less than the FTC's estimate and is more consistent with the indivisibility theory. But Hausman's approach has two weaknesses, weaknesses that make additional empirical analysis desirable. It offers no reason for the simple observation that prices were higher in one-firm markets. This is a serious weakness because that observation seemed to significantly influence the court. Second, Baker argued that Hausman's procedure is susceptible to error because the exact date the entrant affects market price is uncertain: the incumbent firm might lower price before actual entry occurs. (Imagine the incumbent having a temporary sale right before the other firm enters; the sale is intended to reduce the number of customers who will sample the new firm.) If so, market price might rise shortly after entry, prompting an incorrect interpretation of the long-run effect of the merger. ${ }^{43}$

A way to test the indivisibility explanation indirectly would be to show that market size helps account for the higher prices observed in one- and two-firm markets. Company documents could be used to determine the average-cost minimizing store size (expressed in terms of area population served) and the average-cost minimizing number of stores in an area. The firms seem to compute such numbers. An Office Depot document listed every market in the U.S., how many office supply superstores were present in the market, along with Office Depot's estimate of how many superstores the area could possibly support. For example, Staples estimated that there was "room" for less than two additional stores in Washington, D.C. and Office Depot estimated there was room for only two additional stores in Tampa ${ }^{44}$

With the average-cost minimizing store size in hand, one could divide total market size by the cost minimizing store size. The remainder from this division, expressed as a percentage of market size, could be a good proxy for indivisibility in store size. For example, suppose the cost-minimizing store size serves a population 100,000. In a market of 250,000 two stores would leave a remainder of 50,000. 50,000 divided by 250,000 would give the indivisibility proxy a value of .20; eight stores in a market of 850,000 would give the proxy a value of about .06, and so on. A variable could also be constructed to proxy for multi-store indivisibility. We would then test whether prices were positively correlated with the proxies of indivisibility.

An additional advantage of using company documents is that they could help resolve questions about geographic market definition. The FTC defined almost all OSS

\footnotetext{
${ }^{41}$ Hausman and Leonard, undated, p. 4.

${ }^{42}$ Ibid.

${ }^{43}$ Baker, 1997, footnote 33.

${ }^{44}$ Dalkir and Warren-Boulton, 1999, p. 156. See also Federal Trade Commission v. Staples, Inc. and Office Depot, Inc., p. 40 and Bulkeley, 1998. (The latter states that Office Max once ignored markets with a population below 200,000.)
} 
markets as metropolitan statistical areas (MSAs). ${ }^{45}$ But this definition might not be appropriate in all cases. Consider the FTC's touted example of Leesburg and Orlando, Florida. In Leesburg, with only a Staples store, prices for five popular items were between 30 and 114\% higher than prices in Orlando with outlets from all three OSS firms. Note, though, that Leesburg is in the Orlando MSA! ${ }^{46}$ If Leesburg and Orlando are in the same economic market - and the FTC's complaint specifies the Orlando metropolitan area as a market ${ }^{47}$ - then there is a large amount of intra-market variation in price that cries out for explanation; if Leesburg and Orlando are really in separate markets, the FTC misspecified at least this one market, raising questions about other market definitions.

If these proxies can not be computed, another approach would be to estimate a cross-section model like the FTC's but with the observations separated into groups by market size. For instance, we could look at markets having a population between 400,000 and 500,000 and ask whether Lakeland (Fla.) and Spokane-two-firm markets-had higher prices than Chattanooga, Kalamazoo, and Passaic - three-firm markets. And we could look at markets having a population between 2.2 and 2.7 million and ask whether Baltimore, San Diego, and Tampa-St. Petersburg had higher prices than Cleveland, Nassau-Suffolk, and Pittsburgh. Within narrow market size groups indivisibility should be roughly the same so that if higher prices were associated with fewer firms, we could more confidently attribute it to non-competitive behavior. (A drawback of this approach is that there are no natural boundaries for the size groupings. But the boundaries could be subjected to a sensitivity analysis.)

\section{Conclusion}

Many retail markets are consolidating; this suggests that the antitrust authorities will be bringing cases similar to Staples for a while to come. The FTC will continue to compare prices across markets. It is important, therefore, that the limitations of such comparisons be understood. Unless indivisibility is controlled for, using price differences among markets to infer price changes within a market is potentially misleading.

\footnotetext{
${ }^{45}$ See Baker, 1997 , p. 10 and footnote 38.

${ }^{46}$ U.S. Census Bureau, "Metropolitan Areas."

${ }^{47}$ Federal Trade Commission, "Plaintiff's Memorandum," April 10, 1997, footnote 24.
} 


\section{References}

Ashenfelter, Orley, et. al. "Identifying the Firm-Specific Cost Pass-Through Rate." Federal Trade Commission, Bureau of Economics, Working Paper No. 217, January 1998.

Baer, William J. "Report from the Bureau of Competition (1999)." Prepared remarks before the American Bar Association Antitrust Section, Federal Trade Commission Committee, April 15, 1999. http://www.ftc.gov/speeches/other/baerspaba99.htm.

Baker, Jonathan B. "Econometric Analysis in FTC v. Staples." Prepared remarks before the American Bar Association's Antitrust Section, Economics Committee, July 18, 1997 (revised March 31, 1998). http://www.ftc.gov/speeches/other/stspch.htm.

Broyles, Phillip L. and Richard Liebeskind. "Staples and Retail Mergers.” Undated. http://www.abanet.org/antitrust/committees/ftc/part7.html.

Bulkeley, William F. “Office-Supply Superstores Find Bounty in the Boonies.” Wall Street Journal, September 10, 1998, p. B1.

Dalkir, Serdar and Frederick R. Warren-Boulton. "Prices, Market Definition, and the Effects of Merger: Staples-Office Depot (1997)," in The Antitrust Revolution: Economics, Competition, and Policy, $3^{\text {rd }}$ Edition by John E. Kwoka, Jr. and Lawrence J. White. New York: Oxford University Press, 1999.

Demsetz, Harold. "Industry Structure, Market Rivalry, and Public Policy." Journal of Law and Economics, April 1973, 1-10.

. "Two Systems of Belief about Monopoly" in Industrial Concentration: The

New Learning, edited by Harvey J. Goldschmid, H. Michael Mann, and J. Fred Weston. Boston: Little, Brown and Company, 1974, 164-184.

- "The Indivisibility Rent Theory of Measured Oligopoly Profit" in The

Organization of Economic Activity, Volume II: Efficiency, Competition, and Policy, by Harold Demsetz. Oxford: Basil Blackwell Ltd, 1989, 112-138.

Donlan, Thomas G. "Market Discipline or Tyranny? Competition Need Not Be Active To Be Effective." Barron's, April 28, 1997.

Doyle, Robert W., Jr. and D. Reed Freeman, Jr. "FTC v. Staples: Impact Analysis for Merging Firms.” http://www.arentfox.com/alerts/ftcvstaples7_18_97.html.

Dunne, Timothy and Mark J. Roberts. "Costs, Demand, and Imperfect Competition as Determinants of Plant-Level Output Prices" in Empirical Studies in Industrial Organization: Essays in Honor of Leonard W. Weiss, edited by David B. Audretsch and John J. Siegfried. Dordrecht: Kluwer Academic Publishers, 1992, pp. 13-33. 
Federal Trade Commission. "FTC Rejects Proposed Settlement In Staples/Office Depot Merger." April 4, 1997. http://www.ftc.gov/opa/1997/9704/stapdep.htm.

Federal Trade Commission v. Staples, Inc. and Office Depot, Inc., "Plaintiff's Memorandum Of Points And Authorities In Support Of Motions For Temporary Restraining Order And Preliminary Injunction.” U. S. District Court for the District of Columbia, 97-701, April 10, 1997.

Federal Trade Commission v. Staples, Inc. and Office Depot, Inc., "Plaintiff's Reply To Defendants' Joint Post-Hearing Memorandum Of Law In Opposition To The Federal Trade Commission's Motion For A Preliminary Injunction." U. S. District Court for the District of Columbia, 97-701, June 6, 1997.

Federal Trade Commission v. Staples, Inc. and Office Depot, Inc., "Redacted Memorandum Opinion.” U. S. District Court for the District of Columbia, 97-701, June 30, 1997.

Hausman, Jerry A. and Gregory K. Leonard. "Documents Versus Econometrics in Staples," undated. http://www.antitrust.org/cases/staples/hausleon.html.

Lambson, Val Eugene. "Is the Concentration-Profit Correlation Partly an Artifact of Lumpy Technology?" American Economic Review, September 1987.

Lopez, Edward J. “New Anti-Merger Theories: A Critique,” Cato Journal, Winter 2001.

Newmark, Craig M. "A New Test of the Price-Concentration Relationship in Grocery Retailing." Economics Letters, August 1990.

.Price and Seller Concentration in Cement: Effective Oligopoly or Misspecified Transportation Cost?" Economics Letters, August 1998.

Niskanen, William A. "Kicking Around the Staples-Office Depot Merger," Legal Times, June 16, 1997.

Pascual, Aixa M. “Can Office Depot Get Back on Track?” Business Week, September 18, 2000.

Pitofsky, Robert. "Staples and Boeing: What They Say About Merger Enforcement at the FTC." Prepared remarks before Antitrust 1998, Business Development Associates, September 23, 1997. http://www.ftc.gov/speeches/pitofsky/STAPLESspc.htm.

Shughart, William F., II. "The Government's War on Mergers: The Fatal Conceit of Antitrust Policy." Cato Policy Analysis No. 323, October 22, 1998. http://www.cato.org/pubs/pas/pa323b.pdf.

Singer, Amy. "Staple Removers," The American Lawyer, October 1997. 
Smith, Fred L., Jr. "The Case for Reforming the Antitrust Regulations (If Repeal Is Not an Option)," Harvard Journal of Law \& Public Policy, Fall 1999.

U. S. Bureau of Economic Analysis. "Regional Economic Information System.” http://fisher.lib.virginia.edu/reis/index.html.

."Metropolitan Areas."

http://www.census.gov/population/www/estimates/metroarea.html. 